\title{
BONUS DEMOGRAFI JAWA BARAT DAN PERENCANAAN PEMBANGUNAN DAERAH: SUDAH SIAPKAH JAWA BARAT?
}

\author{
Nina Minawati Muhaemin \\ Magister Ilmu Pemerintahan Unpad \\ ninaminawati@yahoo.com
}

\begin{abstract}
Abstrak
Jawa Barat merupakan salah satu Provinsi yang diproyeksikan akan mengalami Bonus Demografi dalam rentang waktu 2020 sampai dengan 2030. Bonus Demografi merupakan keadaan kependudukan suatu negara dengan komposisi penduduk usia produktif (15-64 tahun) mendominasi jumlah penduduk usia tidak produktif (0-14 tahun dan 65+ tahun). Keadaan ini dapat menjadi peluang sekaligus ancaman bagi Jawa Barat. Jika Bonus Demografi ini mampu dipersiapkan, maka akan mendatangkan manfaat berupa peningkatan pertumbuhan ekonomi melalui pemanfaatan Sumber Daya Manusia (SDM) sebagai modal pembangunan. Sebaliknya, jika tidak dipersiapkan dengan baik, bonus demografi dapat menjadi bencana kependudukan, salah satunya dengan meningkatnya tingkat pengangguran. Untuk mempersiapkan Bonus Demografi, pemerintah Jawa Barat perlu memberikan perhatian terhadap beberapa lingkungan kebijakan yang dapat mendukung tercapainya manfaat Bonus Demografi, yakni: kebijakan di bidang kesehatan, keluarga berencana, pendidikan, dan kebijakan di bidang ekonomi. Untuk itu, melalui studi pustaka terhadap dokumen RPJMD Provinsi Jawa Barat Tahun 2018-2023, penelitin ini bertujuan untuk memberikan analisis deskriptif tentang bagaimana Pemerintah Provinsi Jawa Barat mempersiapkan pembangunan daerah dalam menghadapi Bonus Demografi. Berdasarkan hasil temuan, dalam RPJMD Jawa Barat Tahun 2018-2023, tiga kebijakan penunjang Bonus Demografi telah masuk ke dalam prioritas pembangunan, yakni bidang kesehatan, pendidikan, dan ekonomi. Sementara itu, bidang pengendalian laju pertumbuhan penduduk melalui program Keluarga Berencana (KB) tidak menjadi prioritas pembangunan.
\end{abstract}

Kata Kunci : Bonus Demografi, Perencanaan Pembangunan Daerah

\begin{abstract}
West Java is projected will embrace Demographic Bonus during 2020 to 2030. Demographic bonus is a condition whereas the composition of the population is dominated by the working age population (15-64 years old). This condition can bring two possibilities, whether it can be a window of opportunity to increase the economic growth, or it can be a demographic disaster. To harnessing this demographic bonus, West Java Government needs pay more attention to certain policy environment such as education, health, family planning, and economic,
\end{abstract}


covered in its development planning document. This study used qualitative approach. This study is focused on analyzing West Java middle term Development planning, referred to Rencana Pembangunan Jangka Menengah (RPJMD) Jawa Barat Tahun 2018-2023. As the result, there are three policy environments that gain more attention in order to embrace demographic bonus, these are: health, education, and economic.

Key words: Demographic Bonus, Local Development Planning

\section{PENDAHULUAN}

Jawa Barat diproyeksikan akan mengalami Bonus Demografi selama rentang waktu 2020 sampai dengan 2030. Bonus Demografi merupakan keadaan kependudukan suatu negara yang mana jumlah penduduk usia produktif lebih banyak dibandingkan dengan jumlah penduduk usia tidak produktif yang ditandai dengan menurunnya rasio ketergantungan penduduk usia produktif terhadap penduduk usia produktif. Dikatakan sebagai "bonus" karena kondisi kependudukan ini dapat menjadi peluang bagi suatu negara untuk meningkatkan pertumbuhan ekonomi dengan memaksimalkan ketersediaan sumber daya manusia yang ada sebagai subjek pembangunan.

Tabel 1.

Proyeksi Penduduk Jawa Barat 2015-2030

\begin{tabular}{|l|l|l|l|l|l|}
\hline \multirow{2}{*}{ No } & \multirow{2}{*}{ Jenis Proyeksi } & \multicolumn{4}{|c|}{ Tahun } \\
\cline { 3 - 6 } & $\mathbf{2 0 1 5}$ & $\mathbf{2 0 2 0}$ & $\mathbf{2 0 2 5}$ & $\mathbf{2 0 3 0}$ \\
\hline 1 & $\begin{array}{l}\text { Jumlah Penduduk } \\
\text { (Ribuan) }\end{array}$ & 46709,6 & 49935,7 & 52785,7 & 55193,8 \\
\hline 2 & $\begin{array}{l}\text { Jumlah penduduk umur } \\
15-64 \text { tahun (\%) }\end{array}$ & 67,7 & 68,3 & 68,3 & 68,4 \\
\hline 3 & $\begin{array}{l}\text { Dependency Ratio } \\
\text { (Persen) }\end{array}$ & 47,7 & 46,4 & 46,4 & 46,2 \\
\hline
\end{tabular}

Berdasarkan tabel 1, dapat dilihat bahwa jumlah penduduk Jawa Barat terus mengalami peningkatan yang mencapai 55 juta penduduk di tahun 2030. Pertambahan tersebut diikuti dengan tingginya persentase penduduk usia produktif (15-64 tahun) yang diproyeksikan mencapai 68,4 persen dari keseluruhan jumlah penduduk pada tahun 2030. Keadaan ini menyebabkan rasio ketergantungan menjadi menurun mencapai 46,2 persen pada tahun 2030. Artinya, beban tanggungan penduduk usia produktif terhadap penduduk usia tidak produktif 
berkurang, sehingga penduduk usia produktif dapat mengalokasikan penghasilannya pada perbaikan kualitas kehidupan melalui investasi dalam kesehatan dan pendidikan, serta dapat meningkatkan tabungan. Iniah yang disebut dengan bonus demografi.

Bonus Demografi dapat berpengaruh terhadap peningkatan pertumbuhan ekonomi suatu negara melalui tiga mekanisme, yakni: tersedianya pasokan tenaga kerja (labor supply); tabungan (Savings); dan modal manusia (human capital) (Bloom, Canning, \& Sevilla, 2003). Pertama, tersedianya pasokan tenaga kerja (labor supply). Transisi demografi berdampak pada ketersediaan pasokan tenaga kerja melalui dua cara. Pertama, tersedianya penduduk usia produktif (15-64 tahun) yang melimpah. Artinya, jumlah penduduk yang bisa bekerja menjadi semakin banyak. Dengan adanya lapangan kerja yang mampu menyerap pasokan tenaga kerja tersebut, diharapkan pendapatan per kapita dapat meningkat. Kedua, wanita memiliki peluang yang besar untuk masuk ke pasar kerja. Hal ini dikarenakan menurunnya jumlah kelahiran membuat wanita dapat lebih fokus untuk mengembangkan diri dan ikut serta dalam perekonomian keluarga.

Kedua, tabungan (savings). Berkurangnya beban tanggungan dalam keluarga membuat penduduk usia produktif dapat lebih banyak menyisihkan penghasilannya untuk ditabung atau diinvestasikan untuk pendidikan anak atau untuk jaminan hari tua. Peningkatan tabungan ini dapat mendorong peningkatan prospek investasi dan pertumbuhan ekonomi suatu negara.

Ketiga, modal manusia (human capital). Bonus demografi memiliki dampak yang signifikan terhadap investasi sumber daya manusia (SDM). Bonus demografi diawali dengan menurunnya tingkat kematian penduduk di suatu negara. Artinya, penduduknya cenderung lebih sehat serta dapat hidup lebih lama. Harapan hidup yang lebih lama menyebabkan perubahan mendasar dalam cara orang hidup. Sikap tentang pendidikan, keluarga, masa tua, peran perempuan, serta sikap dalam bekerja cenderung berubah. Artinya, melalui bonus demografi ini, sebuah bangsa yang mengalami serta yang mampu memanfaatkannya mengalami perubahan secara mendasar terhadap cara hidupnya, dan menjadikan orang-orangnya menjadi aset yang berharga sebagai modal manusia dalam pembangunan. Seiring 
meningkatnya usia harapan hidup, orangtua cenderung memilih untuk mendidik anak mereka ke tingkat yang lebih tinggi serta lebih memperhatikan kesehatan dan tumbuh kembang anak.

Namun demikian, Bonus demografi datang dengan dua kemungkinan, yakni, sebagai peluang atau sebagai ancaman. Seperti yang dikatakan sebelumnya, keberhasilan dalam memanfaatkan bonus demografi dapat membantu suatu negara dalam meningkatkan pertumbuhan ekonominya, sebaliknya, kegagalan dalam mempersiapkan Bonus Demografi pada akhirnya justru dapat menjadikan bonus demografi sebagai bencana demografi.

Terdapat beberapa negara yang telah meraih manfaat bonus demografi, diantaranya adalah Irlandia dan Jepang (Bloom, Canning, \& Sevilla, 2003). Pertumbuhan ekonomi Irlandia meningkat pesat dari 3,5 persen pada tahun 1960 menjadi 5,8 persen pada tahun 1990 jauh melebihi negara-negara Eropa lainnya hingga dijuluki sebagai Irish Tiger (Harimau Irlandia). Pertumbuhan ekonomi ini salah satunya dikarenakan meningkatnya partisipasi wanita dalam kegiatan perekonomian sepanjang tahun 1980 sampai dengan tahun 2000.

Negara selanjutnya ialah Jepang. Jepang mengalami pengingkatan pertumbuhan ekonomi meskipun sempat terpuruk pasca Perang Dunia II. Peningkatan angka kelahiran (Fertility) dan penurunan angka kematian (Mortality) membuat Jepang mengalami Bonus Demografi yang mampu dimanfaatkan. Adanya upaya pemerintah, tersedianya tenaga kerja terdidik, serta fokus pada pengembangan industri dan teknologi membuat Jepang mampu meraih sukses dalam pengingkatan pertumbuhan ekonomi.

Lain halnya dengan Jepang dan Irlandia, Sub Sahara Afrika justru tidak dapat menikmati manfaat bonus demografi. Berdasarkan laporan Bank Dunia (Lange, Wodon, \& Carey(eds), 2018), beberapa negara berpenghasilan rendah terutama di Sub Sahara Afrika mengalami penurunan pendapatan perkapita sebanyak 2 persen. Bahkan, angka kemiskinan terus melonjak selama dekade terakhir. Hal ini dikarenakan pertumbuhan populasi dan peluang bonus demografi yang dimiliki tidak mampu dimaksimalkan. Padahal, menurut Bank Dunia, Sub Sahara Afrika dapat meraih bonus demografi jika saja mampu meningkatkan 
investasi dalam infrastruktur dan pendidikan. Namun, Sub Sahara Afrika tidak bisa memanfaatkan sumberdaya yang tersedia untuk membangun sumber daya manusianya.

Pemerintah memiliki peran yang sangat penting untuk dapat merengkuh manfaat bonus demografi, yakni dengan membuat kebijakan yang dapat mendukung tercapainya manfaat bonus demografi. Adapun beberapa lingkungan kebijakan tesebut, yakni: kebijakan di bidang-bidang peningkatan kualitas SDM termasuk peningkatan kualitas pendidikan dan kesehatan masyarakat; bidang ekonomi termasuk di dalamnya menciptakan lapangan kerja baru; serta kebijakan di bidang keluarga berencana termasuk di dalamnya pengendalian angka fertilitas (Bloom, Canning, \& Sevilla, 2003) (Remie, et al., 2019)

Bonus demografi ini membuat lingkungkan-lingkungan kebijakan tersebut menjadi hal yang penting untuk mendapat perhatian lebih dari pemerintah provinsi Jawa Barat, utamanya dalam merencanakan pembangunan daerah, salah satunya yakni dalam Rencana Pembangunan Jangka Menengah Daerah (RPJMD) Tahun 2018-2023 Provinsi Jawa Barat. Berdasarkan hal tersebut, rumusan masalah yang akan diketengahkan dalam penelitian ini adalah : "Apakah RPJMD Provinsi Jawa Barat Tahun 2018-2023 telah mampu merespon serta menjadi strategi yang tepat dalam mempersiapkan bonus demografi di Jawa Barat?

Adapun urgensi dari penelitian ini dapat uraikan sebagai berikut:

1. Sebagai respon terhadap hasil penelitian dari disiplin ilmu lain yang berimplikasi terhadap disiplin ilmu pemerintahan. Meskipun setiap disiplin ilmu memiliki area tertentu yang dipelajarinya, tetapi, setiap disiplin ilmu memiliki keterkaitan. Sebuah penelitian dari satu disiplin ilmu seringkali membuka peluang bagi penelitian baru di disiplin ilmu lainnya (Baronett, 2017). Bonus demografi berawal dari studi tentang pertumbuhan dan perubahan struktur kependudukan. Perubahan struktur kependudukan ini, oleh para ekonom dianggap memiliki pengaruh terhadap pertumbuhan ekonomi yang saat ini disebut dengan Bonus Demografi, dengan syarat tersedianya sumberdaya manusia yang berkualitas serta tersedianya pasar kerja yang memadai. Dalam hal ini, sebagai bahan masukan, terdapat 
beberapa implikasi kebijakan yang tentunya membutuhkan peran pemerintah (Brander \& Dowrick, 1994) (Bloom, Canning, \& Sevilla, 2003) (Bongaarts, 2009) (Short, 2009) (Sinding, 2009); (Mason, Lee, \& Lee, 2010) (Bloom, Canning, \& Finlay, 2010) (Remie, et al., 2019), yang kemudian membuka peluang untuk melaukan sebuah penelitian di ranah disiplin ilmu pemerintahan.

2. Adanya kekosongan penelitian. Pemerintah dan bonus demografi ini, telah diketengahkan beberapa diskursus. seperti diskursus tentang Kebijakankebijakan strategis untuk mempersiapkan Bonus Demografi di Indonesia (Wisnumurti, Darma, \& Suasih, 2018), (Hendratno, 2015), diskursus tentang potensi wilayah dalam menghadapi bonus demografi (Syamsul \& Pakaya, 2018). Adapun diskursus tentang perencanaan pembangunan dan bonus demografi yang telah dilakukan oleh Putro (2015) lebih menekankan analisis terhadap kompleksitas kependudukan Papua dalam sektor ekonomi, pendidikan, dan kesehatan yang pada akhirnya menghasilkan beberapa rekomendasi untuk diperhatikan dalam merencanakan pembangunan di Papua. Sementara itu, penelitian ini bertujuan untuk menganalisis dokumen perencanaan pembangunan Jawa Barat, yakni RPJMD Provinsi Jawa Barat Tahun 2018-2023. Jawa Barat merupakan Provinsi dengan jumlah penduduk terbanyak di Indonesia. Artinya, percepatan pembangunan di Jawa Barat melalui pemanfaatan Bonus Demografi dapat membantu percepatan pembangunan nasional secara signifikan.

3. RPJMD Provinsi Jawa Barat tahun 2018-2023 menjadi dokumen yang sangat strategis untuk mempersiapkan Jawa Barat dalam menghadapi bonus demografi. Diharapkan, perencanaan pembangunan periode ini dapat mendukung tercapainya manfaat bonus demografi.

Adapun metode yang digunakan dalam penulisan ini ialah deskritif analitis dengan menganalisis data yang diperoleh melalui studi kepustakaan. Dalam hal ini , dokumen yang menjadi sumber utama analisis ialah dokumen RPJMD Provinsi Jawa Barat Tahun 2018-2023 yang terlampir dalam Peraturan Daerah Provinsi Jawa 
Barat Nomor 8 Tahun 2019 tentang Rencana Pembangunan Jangka Menengah Daerah Provinsi Jawa Barat Tahun 2018-2023.

\section{PEMBAHASAN}

Jawa Barat merupakan Provinsi dengan jumlah penduduk terbanyak di Indonesia. Jumlah penduduk di Provinsi Jawa Barat mencapai 43 juta jiwa atau sekitar 18 persen dari total penduduk Indonesia. ${ }^{1}$ Berdasarkan data dari BPS Jawa Barat tahun 2019, bahwa penduduk Jawa Barat terdiri atas 12, 83 juta jiwa (26, 02 persen) merupakan penduduk usia muda (0-14 tahun), sebanyak 33, 62 juta jiwa $(68,18$ persen) merupakan penduduk usia produktif (15-64 tahun), dan sebanyak 2,86 juta jiwa (5,80 persen) merupakan penduduk usia tua (lebih dari 64 tahun). Hal ini menggambarkan tingginya jumlah usia produktif di Jawa Barat, sehingga diharapkan dapat menjadi modal pembangunan yang dapat meingkatkan pertumbuhan ekonomi di Jawa Barat.

Tabel 2

Persentase penduduk Jawa Barat berdasarkan klasifikasi usia

\begin{tabular}{|l|l|l|l|}
\hline \multicolumn{1}{|c|}{ Tahun } & \multicolumn{1}{|c|}{ Usia muda (0-15) } & Usia Produktif (15-64) & Usia Tua ( >64) \\
\hline 2015 & $27,17 \%$ & $67,74 \%$ & $5,08 \%$ \\
\hline 2020 & $25,74 \%$ & $68,22 \%$ & $6,03 \%$ \\
\hline 2025 & $24,29 \%$ & $68,33 \%$ & $7,38 \%$ \\
\hline 2030 & $22,61 \%$ & $68,41 \%$ & $8,98 \%$ \\
\hline
\end{tabular}

Sumber data: Bappenas (2013)

Berdasarkan tabel di atas, dapat dilihat bahwa persentase jumlah penduduk usia muda (0-15 tahun) terus mengalami penurunan, sementara persentase penduduk usia produktif (15-64 tahun) dan penduduk usia tua (>64 tahun) terus mengalami peningkatan. Peningkatan presentase jumlah penduduk usia tua akan terus bertambah seiring dengan transisi penduduk usia produktif menjadi penduduk usia tua.

\footnotetext{
${ }^{1}$ Berdasarkan jumlah sensus penduduk tahun 2010 dalam bahan publikasi tim pusat data dan analisis pembangunan Bappeda Jabar. 2014. "Pertumbuhan Penduduk di Provinsi Jawa Barat: Potensi Pembangunan ataukah Malapetaka?"
} 


\section{A. Tantangan Jawa Barat menghadapi Bonus Demografi}

Menghadapi bonus demografi ini, jawa barat dihadapkan pada kondisikondisi yang dapat menjadi tantangan dalam meraih manfaat bonus demografi. Bonus Demografi menekankan pada pemanfaatan sumber daya manusia sebagai modal pembangunan. Namun, Indeks Pembangunan Manusia (IPM) Jawa Barat masih rendah dengan menempati posisi ke- 16 dari semua provinsi di Indonesia. Pada tahun 2017, IPM Jawa barat sebesar 70,69 masih lebih rendah dari IPM Nasional yang mencapai 70,81. Sementara itu, penduduk Jawa Barat dihadapkan dengan Asean Economic Community (AEC) yang mengharuskan penduduk Jawa Barat untuk mampu bersaing dengan tenaga kerja asing dengan IPM yang lebih baik.

Dalam bidang pendidikan, Jawa Barat masih memiliki tingkat rata-rata lama sekolah yang masih rendah, yakni 8,2 tahun. Artinya, rata-rata penduduk Jawa Barat hanya mampu mengenyam pendidikan sampai pada kelas 8 pada tingkat sekolah menengah pertama dan tidak sampai lulus. Rendahnya rata-rata lama sekolah ini dipengaruhi oleh tiga faktor, yakni: ekonomi, kemiskinan, dan budaya. Banyak anak yang tidak sekolah karena orangtua yang tidak mampu membiayai pendidikan anak (ekonomi dan kemisikinan). Bahkan, masih terdapat anggapan bahwa anak perempuan tidak perlu mendapatkan pendidikan yang tinggi (budaya). ${ }^{2}$

Di bidang kesehatan, Jawa barat dihadapkan pada tingginya jumlah balita yang mengalami stunting ${ }^{3}$. Bahkan, angka stunting Jawa Barat lebih tinggi dari nasional (27 persen), yakni 38 persen. Angka yang tinggi ini disumbang oleh 13 Kabupaten/kota di Jawa Barat dengan angka Stunting tinggi, yakni: Kabupaten Garut (43,2 persen); Kabupaten Sukabumi (37,6 persen; Kabupaten Cianjur (35,7

\footnotetext{
${ }^{2}$ Berdasarkan penelitian yang dilakukan oleh Badan Pusat Statistika yang didukung oleh Hafiza (2013) yang dimuat dalam bahan publikasi tim pusat data dan analisis pembangunan Bappeda Jabar. 2014. "Pertumbuhan Penduduk di Provinsi Jawa Barat: Potensi Pembangunan ataukah Malapetaka?"

${ }^{3}$ Stunting adalah kondisi gagal pertumbuhan pada anak (pertumbuhan tubuh dan otak) akbiat kekurangan gizi dalam waktu yang lama. Sehingga, anak lebih pendek atau perawakan pendek dari anak normal seusianya dan memiliki keterlambatan dalam berpikir ( http://awalbros.com/anak/kenali-stunting-dan-carapencegahannya/\#: :text=Stunting\%20adalah\%20kondisi\%20gagal\%20pertumbuhan,tidak\%20ses uai\%20dengan\%20kebutuhan\%20gizi. Diakses pada 1 oktober 2020
} 
persen); Kabupaten Tasikmalaya (33,3 persen); Kabupaten Bandung Barat (34,2 persen); Kabupaten Bogor (28,29 persen); Kabupaten Bandung (40,7 persen); Kabupaten Kuningan (42 persen); Kabupaten Cirebon (42,47 persen); Kabupaten Sumedang (41,08 persen); Kabupaten Indramayu (36,12 persen); Kabupaten Subang (40,47 persen); dan Kabupaten Karawang (34,87 persen). ${ }^{4}$ Kondisi ini dapat mengancam ketersediaan penduduk Jawa Barat yang berkualitas di masa depan.

Selain itu, angka kematian ibu dan bayi di Jawa Barat masih cenderung tinggi. Berdasarkan laopran dinas kesehatan jawa barat, Angka kematian ibu meningkat dari 748 kasus di tahun 2014 menjadi 823 kasus di tahun 2015. Sementara itu, angka kematian bayi meningkat dari 3098 kasus di 2014 menjadi 3369 kasus di 2015. Jika dirata-ratakan, pada tahun 2015 Jawa Barat kehilangan 2 ibu dan 9 bayi setia harinya. ${ }^{5}$ Sebuah studi yang dilakukan oleh Astuti (2013) dengan lokus Depok menunjukkan bahwa sekitar 33,3 persen dari perempuan yang mengandung di usia di bawah 20 tahun mengalami komplikasi di masa kehamilan dan pada saat melahirkan yang berpotensi menimbulkan kematian ibu. ${ }^{6}$

Bukan hanya stunting. Penduduk usia produktif Jawa Barat pun masih dibayang-bayangi oleh tingginya angka penyakit menular seperti HIV yang mengancam penduduk usia produktif. Jawa Barat menjadi Provinsi dengan peringkat ke-4 dalam jumlah kasus kumulatif HIV/AIDS secara nasional. Berdasarkan laporan ditjen P2P, Kemenkes RI, Jumlah kasus kumulatif HIV/AIDS dari tahun 1987 sampai dengan Maret 2020 berjumlah 49.440 kasus yang terdiri dari 41.878 untuk kasus HIV dan 7.562 untuk kasus AIDS. ${ }^{7}$

Di bidang ketenagakerjaan, Jawa Barat merupakan provinsi penyumbang pengangguran terbuka tertinggi di Indonesia yakni sebesar 8,89 persen di tahun

\footnotetext{
4 Pemprov Jabar.2018. 13 Kabupaten di Jabar Kasus Stunting Tinggi. https://jabarprov.go.id/index.php/news/30750/2018/11/18/13-Kabupaten-di-Jabar-KasusStunting-Tinggi (diakses pada 1 Oktober 2020)

5 Angka kematian ibu dan bayi di Jabar tertinggi. PikiranRakyat.com (https://www.pikiranrakyat.com/bandung-raya/pr-01268825/angka-kematian-ibu-dan-bayi-di-jabar-tertinggi-386404)

6 Anggraini Sri Astuti. 2013. Youth Perspectives for Adolescents Pregnancy in Indonesia: A Systematic Review. Dipublikasikan pada Asia Pasific Conference on Sexual Reproductive Health and Rights (APCRSHR) ke 7. Manila 2014.

7 Syaiful W Harahap. 2020. Jawa Barat di Peringkat 4 Jumlah Kumulatif HIV/AIDS. Tagar.id (https://www.tagar.id/jawa-barat-di-peringkat-4-jumlah-kumulatif-hivaids)
} 
2016, dengan tingkat partisipasi angkatan kerja (TPAK) yang rendah sebesar 60,65 persen. Sekitar 30 sampai dengan 40 persen penduduk usia produktif di Jawa Barat merupakan lulusan Sekolah Dasar (SD) ${ }^{8} 54$ persen atau lebih dari setengah tenaga kerja di Jawa Barat adalah pekerja informal di sektor pertanian dan non-pertanian. Sementara itu, sisanya, sekitar 8 persen ialah tenaga kerja yang memiliki kontrak yang jelas (3,6 persen), pegawai tetap ( 3 persen), serta pengusahan dan lain-lain ( 2 persen). ${ }^{9}$

Salah satu yang menjadi komponen dalam pemanfaatan bonus demografi ialah partisipasi perempuan dalam angkatan kerja. Namun, tingkat partisipasi angkatan kerja perempuan yang masih rendah. Berdasarkan data Badan Pusat Statistik (Februari 2018), TPAK perempuan hanya 47,46 persen, sedangkan TPAK laki-laki mencapai 79,89 persen. Sebuah penelitian yang berfokus di Depok, Jawa Barat, menunjukkan bahwa usia ibu termuda ialah 16 tahun. ${ }^{10}$ Artinya, pernikahan di bawah umur masih ditemui di Jawa Barat, terutama di Depok, sehingga menghambat pemberdayaan perempuan terutama dalam hal peningkatan taraf pendidikan.

Aspek lainnya yang penting untuk diperhatikan dalam memetik manfaat bonus demogafi adalah pengendalian penduduk. Laju pertumbuhan penduduk masih tinggi. Selain itu, program Keluarga Berencana (KB) terus menurun. Pada tahun 2017, dari sekitar 9,3 juta jumlah pasangan usia subur (PUS), hanya 1,02 juta (PUS) yang aktif KB. ${ }^{11}$

\footnotetext{
8 Sensus Penduduk, 2010 dalam bahan publikasi tim pusat data dan analisis pembangunan Bappeda Jabar. 2014. "Pertumbuhan Penduduk di Provinsi Jawa Barat: Potensi Pembangunan ataukah Malapetaka?"

${ }^{9}$ World Bank, 2012 dalam bahan publikasi tim pusat data dan analisis pembangunan Bappeda Jabar. 2014. "Pertumbuhan Penduduk di Provinsi Jawa Barat: Potensi Pembangunan ataukah Malapetaka?"

10 Anggraini Sri Astuti. 2013. Youth Perspectives for Adolescents Pregnancy in Indonesia: A Systematic Review. Dipublikasikan pada Asia Pasific Conference on Sexual Reproductive Health and Rights (APCRSHR) ke 7. Manila 2014.

11 Jawa Barat dalam Angka 2019
} 


\section{B. Rencana Pembangunan Jangka Menengah Daerah Jawa Barat 2018- 2023}

RPJMD Provinsi Jawa Barat Tahun 2018-2023 merupakan penjabaran visi, misi, dan program kepala daerah terpilih. Dokumen ini memuat tujuan, sasaran, strategi, arah kebijakan, pembangunan daerah dan keuangan daerah, serta program perangkat daerah dan lintas perangkat daerah yang disertai dengan kerangka pendanaan bersifat indikatif untuk jangka waktu lima tahun yang disusun dengan berpedoman pada RPJMD dan RPJMN.

Dalam penyusunan RPJMD, pemerintah provinsi Jawa Barat menggunakan beberapa pendekatan yang diatur dalam Undang-Undang Nomor 25 Tahun 2004 tentang Sistem Perencanaan Pembangunan Nasional, yakni sebagai berikut: (1) Pendekatan teknokratis, yakni pendekatan dengan metode menggunakan metode dan kerangka berpikir ilmiah untuk mencapai tujuan dan sasaran pembangunan daerah; (2) Pendekatan partisipatif, yakni pendekatan dengan melibatkan berbagai pemangku kepentingan; (3) Pendekatan politis, yakni suatu pendekatan yang dilaksanakan dengan menerjemahkan visi dan misi kepala daerah terpilih ke dalam dokumen perencanaan pembangunan jangka menegah yang dibahas bersama dengan DPRD; dan (4) Pendekatan atas-bawah dan bawah-atas, yakni penedakatan yang menggunakan hasil perencanaan yang diselaraskan dalam musyawarah pembangunan yang dilaksanakan mulai dari Desa, Kecamatan, Daerah kabupaten/kota, Daerah provinsi, hingga nasional.

Adapun prioritas pembangunan Jawa Barat tahun 2018-2023 ialah:

1. Akses pendidikan untuk semua

2. Desentralisasi pelayanan kesehatan

3. Pertumbuhan ekonomi umat berbasis inovasi

4. Pengembangan destinasi dan infrastruktur pariwisata

5. Pendidikan agama dan tempat ibadah juara

6. Infrastruktur konektivitas wilayah

7. Gerakan membangun desa (Gerbang Desa)

8. Subsidi gratis golongan ekonomi lemah (Golekmah)

9. Inovasi pelayanan publik dan penataan daerah 
RPJMD Jawa Barat Tahun 2018-2023 merupakan tahap pembangunan keempat dari RPJPD Provinsi Jawa Barat 2005-2025, yang bertemakan "Mencapai Kemandirian Masyarakat Jawa Barat”. Kemudian tema ini akan dijabarkan setiap tahunnya dan menjadi tema pembangunan dalam RKPD, sebagai berikut:

- 2019: peningkatan kesejahteraan masyarakat dan pelayanan publik

- 2020: Pemantapan kesejahteraan masyarakat dan pelayanan publik

- 2021: Peningkatan daya saing daerah

- 2022: Pemantapan daya saing daerah menuju kemandirian

- 2023: Mencapai kemandirian masyarakat

Berkenaan dengan isu bonus demografi dan perencanaan pembangunan ini, hal pertama yang perlu diidentifikasi adalah kesadaran pemerintah Provinsi Jawa Barat tentang bonus demografi Jawa Barat. Pada tahun 2010, pemerintah Jawa Barat mengadakan revisi terhadap RPJPD Provinsi Jawa Barat Tahun 2005-2025 dengan secara eksplisit mengetengahkan pembahasan tentang bonus demografi yang menjadi salah satu alasan perubahan terhadap dokumen perencanaan itu. ${ }^{12}$ Artinya, RPJMD sebagai turunan dari RPJPD harus memperhatikan hal-hal yang diamanatkan dalam RPJPD. Selanjutnya, pada tahun 2014, Tim Pusat Data dan Analisis Pembangunan Bappeda Jabar telah mempublikasikan hasil analisis tentang pertumbuhan penduduk di Provinsi Jawa Barat yang isinya mengetengahkan tentang isu bonus demografi dan kesiapan Jawa Barat dalam menghadapinya.

\section{Lingkungan Kebijakan Penunjang Bonus Demografi dalam RPJMD Provinsi Jawa Barat Tahun 2018-2023}

Terdapat beberapa lingungan kebijakan yang perlu diperhatikan yang dapat mendukung terengkuhnya manfaat bonus demografi, yakni bidang kesehatan, pendidikan, Pengendalian penduduk/Keluarga Berencana, dan bidang ekonomi (Bloom, Canning, \& Sevilla, 2003). Untuk itu, penting kiranya untuk melihat bagaimana pembangunan di lingkungan-lingkungan kebijakan penunjang bonus

${ }^{12}$ Baca bagian latar belakang pada RPJPD Jabar Tahun 2005-2025 
demografi ini direncanakan dalam dokumen RPJMD Provinsi Jawa Barat tahun 2018-2023.

\section{Bidang Pendidikan}

Melalui pembangunan di bidang pendidikan, diharapkan SDM yang tersedia, terutama penduduk usia produktif, menjadi SDM yang berkualitas yang memiliki kemampuan baik softskill maupun hardskill untuk bisa bersaing dengan bangsa lain, terutama di era Masyarakat Ekonomi Asean (MEA) ini. Karena tidak bisa dipungkiri, tingkat pendidikan masih menjadi salah satu indikator dalam mengukur kualitas SDM. Dalam sektor formal, tingkat pendidikan menjadi syarat yang diperlukan.

Di dalam RPJMD Jawa Barat Tahun 2018-2023, bidang pendidikan menjadi salah satu program pembangunan daerah, yang bersifat strategis, sehingga pelaksanaan dan penganggarannya diutamakan. Program unggulan Gubernur dan Wakil Gubernur Provinsi Jawa Barat Tahun 2018-2023 di bidang pendidikan ialah Program Akses Pendidikan untuk Semua yang diterjemahkan dalam Jabar Juara sebagai berikut:

Program akses pendidikan untuk semua lebih mengarah pada pemerataan pendidikan untuk mendorong kabupaten/kota dengan tingkat partisipasi pendidikan menengah yang masih rendah untuk meningkatkan kualitas pendidikannya. Program ini juga diarahkan agar pendidikan dapat dijangkau oleh kelompok miskin. Program ini diwujudkan dalam dalam satu kebijakan yang disebut sekolah JUARA. Sekolah JUARA terdiri dari Kelas Pintar, yakni kelas yang dilengkapi dengan teknologi serta adanya kelas jarak jauh sehingga akses pendidikan dapat dirasakan untuk semua kalangan; pembuatan sekolah dan ruang kelas baru; sekolah gratis bagi yang membutuhkan, serta beasiswa perguruan tinggi bagi siswa/santri yang berprestasi atau kurang mampu.

Upaya perbaikan di bidang pendidikan di Jawa Barat tidak terbatas hanya pada pendidikan umum saja, dalam RPJMD Provinsi Jawa Barat Tahun 2018-2023 pembangunan di pendidikan keagamaan pun diutamakan. Hal ini terlihat dari adanya program unggulan Pesantren Juara yang rencana pembangunannya meliputi: adanya modernisasi dana umat; adanya tunjangan santri dan ulama; 
modernisasi manajemen pesantren; dan adanya program Satu Pesantren Satu Produk (OPOP) untuk mengajarkan santri berwirausaha.

Pendidikan perempuan pun mendapatkan perhatian dari pemerintah Jawa Barat. Melalui program Perempuan Juara, Pemerintah Jawa Barat berupaya untuk memaksimalkan pemberdayaan terhadap perempuan. Perempuan Juara merupakan program pembuatan sekolah khususnya di perdesaan yang dikhususkan untuk perempuan agar bisa lebih bereksplorasi dalam menggali potensi dan mampu mencapai cita-citanya.

Dengan adanya upaya-upaya tersebut di atas, diharapkan terjadi peningkatan dalam aksesibilitas dan mutu pendidikan di Jawa Barat. Untuk ratarata lama sekolah ditargetkan meningkat menjadi 11, 68 tahun pada 2023, dari kondisi awal 8,14 tahun pada tahun 2017. Sementara itu, angka harapan lama sekolah ditargetkan meningkat dari 12,43 tahun pada tahun 2017 menjadi 13,42 tahun pada tahun 2023.

Rata-rata lama sekolah Jawa Barat pada RPJMD Jawa Barat Tahun 20182023 ditargetkan mencapai 11,68 tahun pada tahun 2023. Artinya, pada tahun 2023, rata-rata penduduk Jawa Barat mengenyam pendidikan sampai pada kelas XI, atau berhenti sebelum kelas XII. Hal ini cukup memprihatinkan, karena meskipun target rata-rata lama sekolah tersebut tercapai, tetapi tetap saja rata-rata penduduk Jawa Barat masih belum bisa menamatkan sekolah pada jenjang pendidikan menengah atas atau hanya lulusan SMP saja.

\section{Bidang Kesehatan}

SDM yang berkualitas juga diperhitungkan dari kualitas kesehatannya. Untuk memanfaatkan bonus demografi, terdapat beberapa kebijakan di bidang kesehatan yang harus diprioritaskan, yakni: kesehatan bayi; kesehatan wanita; kesehatan anak dan jaminan kesehatan pekerja.

Pertama, pemerintah harus mengutamakan kesehatan bayi-bayi yang baru lahir sehingga mampu bertahan hidup. Bukan hanya itu, asupan gizi dan nutrisi pun harus diperhatikan agar tidak mengganggu tumbuh kembang anak. Kedua, kesehatan wanita. Kesehatan wanita amat sangat penting. Kesehatan organ reproduksi pada wanita untuk dapat melahirkan bayi-bayi yang sehat. Pengetahuan 
dan kesadaran wanita akan kesehatan dapat mempengaruhi peningkatan kesehatan keluarga. Ketiga, perbaikan gizi dan nutrisi pada anak. Kesehatan pada anak akan berdampak pada kemampuan kognitif anak. Terakhir, adanya jaminan kesehatan bagi pekerja. Para penduduk usia produktif yang sedang memasuki pasar kerja pun harus diperhatikan kesehatannya, agar tidak mereka bisa bekerja secara maksimal dan tetap produktif.

Sama halnya dengan bidang pendidikan, bidang kesehatan masuk ke dalam program strategis pembangunan daerah dalam RPJMD Jawa Barat 2018-2023. Program unggulan 2018-2023 dalam bidang kesehatan, yakni desentralisasi pelayanan kesehatan yang meliputi:

1. Layad rawat, yang merupakan program di mana para dokter dan tenaga medis melakukan kunjungan ke rumah-rumah masyarakat kabupaten/kota tanpa dipungut biaya. Masyarakat dapat menjangkau mereka setelah sebelumnya melakukan panggilan darurat melalui telepon atau media online.

2. Puskesmas Juara, yakni upaya pemerintah Provinsi Jawa Barat dalam meningkatkan kualitas pelayanan puskesmas dengan menyediakan sarana dan prasarana yang memadai.

3. Pembangunan dan revitalisasi rumah sakit, yakni upaya pemerintah Jawa Barat untuk melakukan revitalisasi terhadap rumah sakit yang kurang layak, dan meningkatkan kualitas rumah sakit tipe $\mathrm{C}$ menjadi tipe $\mathrm{B}$, serta membangun rumah sakit baru.

4. Mobil kekasih, yakni program untuk menjaga kesehatan kejiwaan penduduk Jawa Barat. Mobil Kekasih (Kendaraan konseling silih asih) merupakan pelayanan konseling yang dilakukan di dalam mobil sebagai media konsultasi permasalahan psikologis yang dihadapi masyarakat Jawa Barat.

5. Jaminan kesehatan masyarakat miskin yang terintegrasi dengan jaminan kesehatan nasional.

Kelima program di atas merupakan upaya untuk menyediakan fasilitas kesehatan yang mudah, murah, dan dapat dijangkau. Terlebih, pemerintah bukan 
hanya memperhatikan kesehatan fisik masyarakat, tetapi juga sadar akan pentingnya kesehatan psikologis masyarakat Jawa Barat. Selain itu, pembangunan di bidang kesehatan juga memperhatikan kesehatan wanita sebagai calon ibu, serta kesehatan ibu dan anak yang diwujudkan dalam program OMABA (ojek makanan bayi). Program ini merupakan suatu layanan antar makanan bergizi yang diberikan kepada ibu hamil, bayi, dan balita. Selain itu, melalui program OMABA, pemerintah turut memperhatikan kesehatan wanita remaja yang merupakan calon ibu dengan memberikan tablet penambah darah bagi para remaja putri.

Sasaran yang ingin dicapai melalui desentralisasi di bidang kesehatan ini ialah meningkatkan kualitas kesehatan masyarakat dan jangkauan pelayanan kesehatan, dengan indikator tingkat usia harapan hidup. Target yang ingin dicapai adalah adanya peningkatan usia harapan hidup dari kondisi awal 72,47 tahun pada 2017 menjadi 73,04 tahun di tahun 2023. Artinya, bayi yang lahir di tahun 2023 memiliki harapan untuk hidup sampai usianya 73 tahun.

\section{Keluarga Berencana}

Untuk meraih bonus demografi, angka kelahiran harus dapat dikendalikan. Hal ini dilakukan agar rasio ketergantungan tidak meningkat yang mengindikasikan beban tanggungan penduduk usia produktif terhadap penduduk usia tidak produktif masih tinggi. Hal ini tentunya akan berdampak pada tingkat investasi dan tabungan penduduk usia produktif tersebut.

Untuk menekan laju pertumbuhan penduduk, serta mengendalikan angka kelahiran, upaya yang dapat dilakukan ialah program keluarga berencana dengan mensosialisaikan penggunaan alat kontrasepsi untuk menunda atau mencegah kehamilan, sehingga kehamilan dapat direncanakan sesuai dengan kesiapan dan kemampuan orangtua.

Dalam RPJMD Provinsi Jawa Barat, laju pertumbuhan penduduk pada tahun 2023 diporyeksikan sebesar 1,41 persen. Angka ini masih terbilang tinggi dan bisa mengancam bonus demografi. Upaya untuk mengendalikan laju pertumbuhan penduduk serta menekan tangkat kelahiran diterjemahkan dalam program kampung Juara. Kampung Juara ialah program untuk menurunkan angka kelahiran dan meningkatkan partisipasi Keluarga Berencana (KB) dengan pemakaian alat 
kontrasepsi bagi warga desa. Dalam upaya menekan laju pertumbuhan penduduk ini, upaya lainnya ialah melalui peningkatan partisipasi masyarakat dalam pendidikan, sehingga pernikahan dini dapat berkurang.

Namun sayangnya, upaya pengendalian laju pertumbuhan penduduk ini tidak terlalu mendapat perhatian dari pemerintah. hal ini terlihat dari tidak masuknya program pengendalian jumlah penduduk ke dalam prioritas pembangunan, sehingga strategi dan arah kebijakan pembangunan jangka menengah Provinsi Jawa Barat tahun 2018-2023 tidak membahas mengenai upaya pengendalian laju pertumbuhan penduduk. Meskipun keberhasilan dalam pembangunan di bidang pendidikan dapat berpengaruh terhadap pencegahan pernikahan usia dini, tetapi upaya pengendalian penduduk tidak bisa hanya bergantung pada hal tersebut. Nyatanya, pengguna aktif KB terus mengalami penurunan. Untuk itu, perlu adanya peningkatan sosialisasi KB terhadap masyarakat baik di desa maupun di kota. Seperti halnya pelayanan kesehatan yang diupayakan dapat mudah dijangkau, pelayanan $\mathrm{KB}$ pun seharusnya diupayakan demikian.

\section{Bidang Ekonomi}

Pada akhirnya, pasokan tenaga kerja yang melimpah, sehat, dan berpendidikan harus terserap dalam pasar kerja. Pemerintah harus mampu menciptakan lapangan kerja untuk bisa menyerap pasokan tenaga kerja yang tersedia. Berkenaan dengan hal ini, meningkatkan daya saing dan produktivitas ekonomi Jawa Barat menjadi salah satu Misi Gubernur jawa barat terpilih. Dalam bidang ekonomi ini, Pemerintah Jawa Barat melalui RPJMD tahun 2018-2023 menyiapkan program unggulan yang tujuannya untuk mengakselerasi pertumbuhan dan pemerataan ekonomi, yang mana program ini masuk ke dalam prioritas pembangunan. Pertama, melalui program unggulan Pertumbuhan Ekonomi Umat Berbasis Inovasi; Kedua, Pengembangan destinasi dan infrastruktur pariwisata; ketiga, program pesantren juara 'One Pontren One Product' serta kredit masyarakat melalui masjid; dan terakhir melalui program unggulan Gerbang Desa (Gerakan Membangun Desa). 
Pertama, program unggulan ekonomi umat berbasis inovasi. Program ini lebih ditujukan pada pemberdayaan KUKM yang didukung oleh urusan perdagangan, perindustrian, dan penanaman modal. Diharapkan program ini dapat berdampak pada peningkatan kualitas perekonomian pada urusan pangan, pertanian, kehutanan, dan kelautan perikanan sehingga mampu meningkatkan kemandirian Jawa Barat pada sektor-sektor tersebut. Program unggulan ini terbagi ke dalam beberapa program turunan yakni: Petani Juara; Nelayan Juara, Pasar Juara; Logistik Juara; UMKM Juara; dan Wiraswasta Juara.

Kedua, ialah program unggulan Pengembangan Destinasi dan Infrastruktur Pariwisata. Hal ini diwujudkan dalam perbaikan infrastruktur di tempat-tempat pariwisata, membangun dan mengembangkan destinasi pariwisata baru, serta melalui pengembangan ekonomi kreatif. Diharapkan, pengembangan potensi pariwisata dapat meningkatkan perekonomian bagi masyarakat lokal di sekitar tempat wisata.

Ketiga, Program pesantren juara. Dalam program ini, pesantren kini bukan hanya sebagai tempat pendidikan agama, tetapi perperan untuk meningkatkan perekonomian umat dengan adanya program One Pontren One Product (OPOP). Artinya, setiap pesantren memiliki satu produk usaha untuk menunjang kemandirian perekonomian pesantren, sekaligus sebagai sarana bagi santri dalam belajar berwirausaha. Selain itu, terdapat juga program kredit masyarakat sejahtera. Program ini menjadikan masjid sebagai pusat pertumbuhan ekonomi melalui pemberian pinjaman modal yang akan diberikan melalui masjid dan tempat ibadah lainnnya yang berdasarkan syariat agama masing-masing.

Terakhir, program unggulan gerakan membangun desa (Gerbang Desa). Program ini bertujuan agar desa dapat dimaksimalkan perannya terutama dalam upaya peningkatan pertumbuhan ekonomi untuk menjadi desa yang mandiri, yang diterjemahkan ke dalam beberapa program turunan, yakni: Satu desa satu BUMDES; Desa Digital yang sudah memanfaatkan teknologi dalam kegiatan ekonomi; dan terakhir pengengembangan desa wisata.

Pada akhirnya, semua program dalam bidang peningkatan ekonomi ini diharapkan dapat menyelesaikan masalah tingkat pengangguran dan kemiskinan 
melalui dukungan terhadap pengembangan dan penciptaan wirausaha baru di tingkat lokal, sehingga Jawa Barat dapat memiliki kemandirian ekonomi yang kuat.

\section{KESIMPULAN}

Manfaat Bonus Demografi Jawa Barat tidak secara otomatis didapatkan. Terdapat beberapa lingkungan kebijakan yang perlu mendapat perhatian pemerintah, yang mana lingkungan kebijakan tersebut dapat mendukung tercapainya manfaat bonus demografi. Adapun lingkungan kebijakan tersebut anrata lain: Kebijakan di bidang kesehatan, Kebijakan di bidang keluarga berencana, kebijakan di bidang pendidikan, dan kebijakan di bidang ekonomi.

Dalam RPJMD Jawa Barat Tahun 2018-2023, tiga bidang kebijakan penunjang bonus demografi masuk ke dalam program unggulan dan menjadi prioritas pembangunan, yakni bidang kesehatan, pendidikan dan bidang ekonomi. Sementara itu, bidang pengendalian penduduk melalui program keluarga berencana tidak menjadi program prioritas.

Tidak masuknya upaya pengendalian laju pertumbuhan penduduk ke dalam prioritas pembangunan dapat mengancam terlaksananya bonus demografi. Salah satu daerah yang tidak mencapai Bonus Demografi karena angka fertilitas yang tinggi ialah Sumatera Barat (Andriani, Pitoyo, \& Pangaribowo, 2018) dan kabupaten Landak (Panggabean, 2017) Hal ini dikarenakan, bonus demografi terjadi ketika jumlah penduduk usia produktif melimpah dengan diikuti penurunan rasio ketergantungan. Jika laju pertumbuhan penduduk melalui peningkatan angka fertilitas tidak dapat dikendalikan, maka rasio ketergantungan akan cenderung tinggi. Pada akhirnya akan berdampak pula pada kemampuan penduduk usia produktif dalam menginvestasikan dan meningkatkan tabungannya. Selain itu, dengan adanya penduduk usia muda (0-14 tahun) di dalam keluarga, akan membuat peran wanita dalam pasar kerja menjadi berkurang karena harus merawat keluarga. 


\section{DAFTAR PUSTAKA}

Andriani, D. S., Pitoyo, A. J., \& Pangaribowo, E. H. (2018). Ketidaktercapaian Bonus Demografi: Pembelajaran Dari Sumatera Barat. Populasi, 1-15.

Anggraini Sri Astuti. 2013. Youth Perspectives for Adolescents Pregnancy in Indonesia: A Systematic Review. Dipublikasikan pada Asia Padific Conference in Sexual Reproductive Health and Rights (APCRSHR) KE 7. Manila 2014.

Badan Pusat Statistik. 2013. Proyeksi Penduduk Indonesia 2010-2035. Badan Pusat Statistik: Jakarta

Badan Pusat Statistik Jawa Barat. Jawa Barat Dalam Angka 2019. Badan Pusat Statistik Jabar: Bandung

Bappeda Jawa Barat. Rencana Pembangunan Jangka Menengah Provinsi Jawa Barat Tahun 2018-2023. Bappeda Jabar: Bandung

Bappeda Jawa Barat. Rencana Pembangunan Jangka Panjang Provinsi Jawa Barat Tahun 2005-2025. Bappeda Jabar: Bandung

Baronett, S. (2017). Journey into Philosophy: An Introduction with Classic and Contemporary Readings. New York: Routledge.

Bloom, D. E., Canning, D., \& Finlay, J. E. (2010). Population Aging and Economic Growth in Asia. In T. Ito, \& A. K. Rose, The Economic Consequences of Demographic Change in East Asia (pp. 61-92). London: The University of Chicago Press.

Bloom, D., Canning, D., \& Sevilla, J. (2003). The Demographic Dividend: A New Perspective on The Economic Consequences of Population Change. Santa Monica: RAND.

Bongaarts, J. (2009). Human Population Growth and The Demographic Transition. Philosophical Transactions of The Royal Society B, 2985-2990.

Brander, J. A., \& Dowrick, S. (1994). The Role of Fertility and Population in Economic Growth: Empirical Result from Aggregate Cross-National Data. Journal of Pupulation Economics, 1-25.

Hendratno, E. T. (2015). The Study of Indonesia's Readiness to Cope With Bonus Demographic: A Review of Population Law. Journal of Indonesian Economy and Business, 195-219.

Lange, G.-M., Wodon, Q., \& Carey(eds), K. (2018). The Changing Wealth of Nations 2018: Buliding A Sustainable Future. Washington DC: World Bank. 
Mason, A., Lee, R., \& Lee, S.-H. (2010). The Demographic Transition and Economic Growth in the Pasific Rim. In T. Ito, \& A. K. Rose, The Economic Consequences of Demographic Change in East Asia (pp. 19-60). London: The University of Chicago Press.

Panggabean, M. (2017). Studi Deskriptif tidak Tercapainya Bonus Demografi di Kabupaten Landak. Jurnal Ekonomi, Bisnis dan Kewirausahaan, 43-58.

Pemrov Jabar. 2018. 13 Kabupaten di Jabar Kasus Stunting Tinggi. (https://jabarprov.go.id/index.php/news/30750/2018/11/18/13-Kabupatendi-Jabar-Kasus-Stunting-Tinggi ) diakses pada 1 Oktober 2020

Pikiran Rakyat. Angka Kematian Ibu dan Bayi Tinggi. (https://www.pikiranrakyat.com/bandung-raya/pr-01268825/angka-kematian-ibu-dan-bayi-dijabar-tertinggi-386404) Diakses pada 1 Oktober 2020

Putro, K. H. (2015). Perencanaan Pembangunan di Papua dan Bonus Demografi 2020. Jurnal Tata Kelola dan Akuntabilitas Keuangan Negara, 49-69.

Remie, S. S., Aditya, Aldo, Wildan, D., Prasetyo, D., Dwitamari, . . Herlambang, M. (2019). Bonus Demografi: Sebuah Perspektif dalam Menumbuhkan Ekonomi di Pulau Jawa. Bandung: Unpad Press.

Short, R. V. (2009). Population Growth In Retrospect and Prospect. Philosopical Transactions of THe Royal Society B, 2971-2974.

Sinding, S. W. (2009). Population, Poverty, And Economic Development. Philosopical Transactions of The Royal Society B, 3023-3030.

Syaiful W Harahap. 2020. Jawa Barat di Peringkat 4 Jumlah Kumulatif HIV/AIDS. Tagar.id (https://www.tagar.id/jawa-barat-di-peringkat-4-jumlah-kumulatifhivaids). Diakses pada 1 Oktober 2020

Syamsul, \& Pakaya, S. (2018). Analisis Potensi Wilayah dalam Pemanfaatan Bonus Demografi di Kabupaten Gorontalo. Economic Resources, 1-15.

Tim Pusat Data dan Analisis Pembangunan Bappeda Jabar. 2014. "Pertumbuhan Penduduk di Provinsi Jawa Barat: Potensi Pembangunan ataukah Malapetaka?’. Bappeda Jawa Barat.

Tobarasi, Inggriani. Kenali Stunting dan Cara Pencegahannya. RS Awal Bros. http://awalbros.com/anak/kenali-stunting-dan-carapencegahannya/\#: : text=Stunting\%20adalah\%20kondisi\%20gagal\%20pe rtumbuhan,tidak\%20sesuai\%20dengan\%20kebutuhan\%20gizi. Diakses pada 1 oktober 2020 
Wisnumurti, A. A., Darma, I. K., \& Suasih, N. N. (2018). Government Policy of Indonesia to Managing Demographic Bonus and Creating Indonesia Gold in 2045. IOSR Journal of Humanities and Social Science, 23-34. 